\title{
HYPOGRAVITY AS A RISK FACTOR FOR INCREASED INTRAOCULAR PRESSURE
}

Valyakh MA ${ }^{1 凶}$, Kats DV ${ }^{1}$, Glazko $\mathrm{NG}^{2}$, Baranov MV³

1 Pirogov Russian National Research Medical University, Moscow, Russia

2 Filatov City Clinical Hospital № 15, Moscow, Russia

${ }^{3}$ Research Institute for Space Medicine, Moscow, Russia

Space medicine has long studied the impact of reduced gravity on the human body. Increasing complaints of insufficient visual acuity during and after space flights have been recently drawing a lot of attention to the effects of hypogravity on astronauts' vision. Abnormally high intraocular pressure (IOP) is one of the most clinically important changes occurring during space missions. It is a serious condition that often causes irreversible damage to the optic nerve and blindness. The aim of this study was to explore the effect of reduced gravity on IOP. The study recruited 48 young healthy men with the mean age of 22 years, who formed 2 equally sized groups. In the experimental group, hypogravity was simulated by placing the subjects into the orthostatic position for 21 days. IOP was measured at 4 time points using a Maklakov tonometer. Z-approximation of the Wilcoxon T test was applied. The average increase in IOP in the experimental group was $3.42 \pm 0.03 \mathrm{mmHg}$ $(p<0.01)$. The changes were, however, transient, and IOP levels went back to normal right after the exposure to hypogravity conditions was terminated.

Keywords: orthostatic body position, hypogravity, space flight, intraocular pressure

Acknowledgement: the authors thank Kats DV, Cand. Sci (Med), Assistant Professor at the Department of Ophthalmology of Pirogov Russian National Research Medical University, for revising the manuscript; Baranov MV Cand. Sci (Med), Vice Principal of Research Institute for Space Medicine, for helping with the recruitment process; Glazko NG, ophthalmologist at Filatov City Clinical Hospital No. 15, for his assistance with data analysis.

Author contribution: Valyakh MA — literature analysis, data acquisition, analysis and interpretation, manuscript preparation; Glazko NG — data analysis; Baranov MV — recruitment of participants; Kats DV — manuscript revision.

Compliance with ethical standards: the study was approved by the Ethics Committee of Pirogov Russian National Research Medical University (Protocol № 150 dated December 14, 2015).

Correspondence should be addressed: Maxim A. Valyakh

Veshniakovskaya 23, Moscow, 111539; maxvalyakh@gmail.com

Received: 03.06.2019 Accepted: 17.06.2019 Published online: 19.06.2019

DOI: 10.24075/brsmu.2019.041

\section{ГИПОГРАВИТАЦИЯ КАК ФАКТОР РИСКА ПОВЫШЕНИЯ УРОВНЯ ВНУТРИГЛАЗНОГО ДАВЛЕНИЯ}

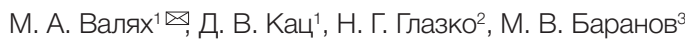

${ }_{1}^{1}$ Российский национальный исследовательский медицинский университет имени Н. И. Пирогова, Москва, Россия

2 Городская клиническая больница № 15 имени О. М. Филатова, Москва, Россия

${ }^{3}$ Научно-исследовательский институт космической медицины, Москва, Россия

Космическая медицина давно занимается исследованием воздействия условий измененной гравитации на организм человека. За последнее время все больше внимания исследователи уделяют изменениям со стороны органа зрения. В первую очередь, это связано с увеличением жалоб космонавтов на недостаточную остроту зрения во время и после окончания космических полетов. Среди наиболее важных изменений у них было обнаружено повышение внутриглазного давления (ВГД) - наиболее опасная патология, нередко приводящая к необратимой слепоте за счет поражения зрительного нерва. Целью исследования было выяснить влияние измененной гравитации на офтальмотонус. Для этого 48 здоровых мужчин, средний возраст которых не превышал 22 года, были разделены на две равные по численности группы: группу контроля и группу, в которой моделировали условия гипогравитации путем помещения испытуемых в ортостатическое положение на время всего эксперимента (21 сутки). Измерение ВГД проводили в четырех контрольных точках эксперимента с помощью тонометра Маклакова. Была использована Z-аппроксимация Т-критерия Уилкоксона. Среднее увеличение ВГД в группе моделирования гипогравитации составило 3,42 \pm 0,03 мм рт. ст. ( $p<0,01)$. Стоит отметить, что данные изменения носили транзиторный характер и после окончания воздействия условий измененной гравитации показатели вернулись к исходным значениям.

Ключевые слова: ортостатическое пложение тела, гипогравитация, космический полет, внутриглазное давление

Благодарности: доценту кафедры офтальмологии имени академика А. П. Нестерова лечебного факультета, кандидату медицинских наук Кацу Д. В. из РНИМУ имени Н. И. Пирогова за редакцию статьи; заместителю директора, кандидату медицинских наук Баранову М. В. из НИИ космической медицинь за помощь в подборе испытуемых; врачу-офтальмологу Глазко Н. Г. из ГКБ № 15 имени О. М. Филатова за обработку полученных данных.

Информация о вкладе авторов: М. А. Валях - анализ литературы, сбор, анализ и интерпретация данных, подготовка рукописи; Н. Г. Глазко обработка полученных данных; М. В. Баранов — подбор испытуемых; Д. В. Кац - редактирование текста статьи.

Соблюдение этических стандартов: исследование одобрено этическим комитетом РНИМУ имени Н. И. Пирогова (протокол № 150 от 14 декабря 2015 г.).

$\checkmark$ Для корреспонденции: Максим Андреевич Валях

ул. Вешняковская, д. 23, г. Москва, 111539; maxvalyakh@gmail.com

Статья получена: 03.06.2019 Статья принята к печати: 17.06.2019 Опубликована онлайн: 19.06.2019

DOI: $10.24075 /$ vrgmu.2019.041

The impact of extraterrestrial gravity on the human body during space missions has long been the subject of scientific research. But it was not until recently that researchers started to look into its effects on the vision of astronauts. There have been reports of elevated intraocular pressure (IOP) following exposure to hypogravity, or a decreased gravitational field. This type of gravity has been discovered on the Moon and is believed to be present on other planets of the Solar System [1-5]

The earliest evidence of elevated IOP during a space flight was obtained using a manual applanation tonometer: it showed a $20-25 \%$ increase in IOP within the first hour after takeoff [6]. 
Other researchers reported elevated IOP in more than half of astronauts during an orbital flight; the measurements were taken with a Tono-pen tonometer [7].

The following study was inspired by the reports of our foreign colleagues about changes to the eye structure and vision during space flights, the growing number of space missions, and the fact that elevated IOP can cause irreversible damage to the optic nerve head, eventually leading to visual impairment or blindness. The aim of the study was to explore how hypogravity affects intraocular pressure. It should be noted that our overseas colleagues also point to other changes that occur to the eye in space; however, none of such changes are as pronounced as an increase in intraocular pressure.

\section{METHODS}

The study was conducted in July 2016 at the facilities of the Department of Ophthalmology (Nesterov Faculty of General Medicine, Pirogov Russian National Research Medical University), Filatov State Clininol Hospital No. 15 and Research Institute for Space Medicine 2

The study recruited 48 male participants (96 eyes) aged 18-35 years who were in good physical shape, had no refractive errors (i.e. were emmetropic) or had mild or moderate myopia (up to -6 diopters). Individuals with acute eye conditions, corneal dystrophy, severe myopia (-6 diopters or more), previous corneal surgery, other pathologies, as well as females or males of different age were excluded from the study. The participants were divided into 2 equally sized groups using sealed envelopes (open-label controlled randomization).

Statistical analysis was carried out in Statistica 8.0 (StatSoft Inc.; USA). Variables that had normal distribution are presented below as $\mathrm{M} \pm m$, where $\mathrm{M}$ is the mean, $m$ is the standard error. For pairwise comparison of two independent samples, the Mann-Whitney $U$ test was applied. For repeated intragroup comparison, the Wilcoxon $\mathrm{T}$ test was used. Significance threshold was $<0.05$

In group 1, hypogravity was simulated at daytime by placing the participants into an orthostatic position so that an angle between the upper part of the body and the horizontal axis was $+9.6^{\circ}$; at night the participants took a horizontal position. The experiment lasted for 21 days. To minimize exposure to any external stimuli, the rooms where the subjects were staying were sound-proof; the windows were locked tight. Only medical staff were allowed into the rooms; visits from family and friends were forbidden. Group 1 could use their phones or computers or read books according to the schedule. Medical tests and personal hygiene procedures could be performed with the participants lying horizontally. Meals could also be taken in bed

Group 2 was the control group. No limitations were imposed on the body position in group 2 at daytime. At night (from $11 \mathrm{pm}$ to $8 \mathrm{am}$ ) the participants lay in bed in the horizontal position. Medical tests were the same as in group 1 and were scheduled on the same days. Group 2 were allowed to take walks on the premises and receive visits from their family and friends. Their rooms were not sound-proof, the windows could be opened any time (Table 1).

For measurements and examinations, 4 basic time points were defined: 1) the time point of initial measurements, which was 1 day before the actual start of the experiment ( i.e. before the participants were placed under simulated hypogravity conditions); 2) day 11 of the experiment; 3) day 21 of the experiment; 4) day 1 after the experiment was over (i.e. after the participants were allowed to leave the premises).

IOP was measured in the morning, because it is when it reaches its maximum, on the days specified above.

Besides, all study participants underwent ophthalmoscopy on the days specified above, as well as computerized perimetry before and after the experiment in order to detect possible damage to the optic nerve.

\section{IOP measurements}

IOP was measured with an applanation Maklakov tonometer (Krasnogvardeets; Russia) that had a $10 \mathrm{~g}$ plunger weight. The obtained data were converted into $\mathrm{mmHg}\left(\mathrm{P}_{0}\right)$ using the Nesterov-Egorov conversion ruler. Normal IOP $\left(P_{0}\right)$ is 10-22 $\mathrm{mmHg}$ when measured with a Maklakov tonometer with a $10 \mathrm{~g}$ plunger weight.

\section{Direct ophthalmoscopy}

Direct ophthalmoscopy of the ocular fundus was performed using a BXa ophthalmoscope (certificate No. 2005/1022; NEITZ; Japan). During the experiment, no eyedrops were used, so the pupils were left undilated for the procedure However, mydriasis was induced to take measurements before the experiment and 1 day after it was over.

\section{Computerized perimetry}

Visual fields were measured by static perimetry using a Humphrey Field Analyzer II 750i (certificate No. 2008/02964; Zeiss; Germany). The analysis of the obtained data accounted for the number of false-positive and false-negative responses and the loss of fixation.

\section{RESULTS}

We observed a statistically significant increase in IOP (3.33 \pm $0.08 \mathrm{mmHg}$ ) in all members of group 1 (the hypogravity model) on day 11. On day 21, IOP continued to grow (the increase was $3.42 \pm 0.03 \mathrm{mmHg}$ ) relative to its value before the experiment. 3 ill, it should be noted that on day 1 after the experiment was completed, IOP dropped to the level comparable to its values before the experiment (Table 2).

Direct ophthalmoscopy revealed no abnormalities in any of the participants in the course of the experiment. The optic disc head was pale pink, excavation was physiological (0.3-0.4). The vascular bundle was localized to the center. The trajectory

Table 1. Characteristics of the groups

\begin{tabular}{|c|c|c|c|}
\hline \multirow{2}{*}{ Groups } & \multicolumn{2}{|c|}{ Parameter } & Spatial body position \\
\cline { 2 - 4 } & $\begin{array}{c}\text { Number of } \\
\text { patients/eyes }\end{array}$ & $\begin{array}{c}\text { The orthostatic position with a }+9.6^{\circ} \text { body tilt at day time } \\
\text { alternated with the horizontal position at night (days 1 through } \\
21 \text { of observation) }\end{array}$ & $\begin{array}{c}\text { Mo limitations on the body position } \\
\text { (days 1 through 21 of observation) }\end{array}$ \\
\hline $\begin{array}{c}\text { Group 1: hypogravity } \\
\text { model }\end{array}$ & $24 / 48$ & $21.75 \pm 3.83$ \\
\hline
\end{tabular}


Table 2. Intraocular pressure in the experimental group

\begin{tabular}{|c|c|c|}
\hline \multirow{2}{*}{ Time points } & \multicolumn{2}{|l|}{ Parameter } \\
\hline & \multicolumn{2}{|c|}{ Mean IOP + standard error, $\mathrm{mmHg}$} \\
\hline Initial & \multicolumn{2}{|l|}{$15,75 \pm 0,72$} \\
\hline \multirow[b]{2}{*}{ Day 11} & \multicolumn{2}{|l|}{$19,08 \pm 0,64$} \\
\hline & $\Delta$ initial - day 11 of the experiment & $\begin{aligned} 3.33 & \pm 0.08 \\
p & <0.01\end{aligned}$ \\
\hline \multirow[b]{2}{*}{ Day 21} & \multicolumn{2}{|l|}{$19.17 \pm 0.69$} \\
\hline & $\Delta$ initial - day 21 of the experiment & $\begin{array}{c}3.42 \pm 0.03 \\
p<0.01\end{array}$ \\
\hline \multirow[b]{2}{*}{ Day 1 after the experiment was completed } & \multicolumn{2}{|l|}{$15.67 \pm 0.62$} \\
\hline & $\Delta$ initial - day 1 after the experiment & $\begin{array}{l}0.08 \pm 0.1 \\
p>0.05\end{array}$ \\
\hline
\end{tabular}

Table 3. Intraocular pressure in the control group

\begin{tabular}{|c|c|c|}
\hline \multirow{2}{*}{ Time points } & \multicolumn{2}{|l|}{ Parameter } \\
\hline & \multicolumn{2}{|c|}{ Mean IOP + standard error, $\mathrm{mmHg}$} \\
\hline Initial & \multicolumn{2}{|l|}{$15.75 \pm 0.72$} \\
\hline \multirow[b]{2}{*}{ Day 11} & \multicolumn{2}{|l|}{$15.79 \pm 0.73$} \\
\hline & $\Delta$ initial - day 11 of the experiment & $\begin{array}{c}0.04 \pm 0.01 \\
p>0.05\end{array}$ \\
\hline \multirow[b]{2}{*}{ Day 21} & \multicolumn{2}{|l|}{$15.71 \pm 0.71$} \\
\hline & $\Delta$ initial - day 21 of the experiment & $\begin{array}{c}0,04 \pm 0.01 \\
p>0.05\end{array}$ \\
\hline \multirow[b]{2}{*}{ Day 1 after the experiment was completed } & \multicolumn{2}{|l|}{$15.77 \pm 0.71$} \\
\hline & $\Delta$ initial — day 1 after the experiment & $\begin{array}{c}0.02 \pm 0.01 \\
p>0.05\end{array}$ \\
\hline
\end{tabular}

and caliber of blood vessels was unchanged. No abnormalities were observed in the macular zone. No peripheral ruptures or dystrophy were noticed.

Computerized perimetry revealed no absolute scotomas or significant enlargement of the blind spot in group 1.

In the control group, IOP was stable throughout the experiment and upon its completion. Its values fell within the normal reference range in all members of group 2 (Table 3). Similar to group 1, no pathologies were detected during direct ophthalmoscopy and computerized perimetry.

Statistical analysis of IOP changes assisted by the MannWhitney $U$ test for two independent samples showed that $U_{\text {emp }}$ was 0 in both groups whereas $U_{\text {crt }}$ was $834(p<0.01)$, suggesting statistical significance and reliability of the obtained results.

\section{DISCUSSION}

Hypogravity causes elevated intraocular pressure. We discovered a reliable and statistically significant increase in IOP that rose by an average of $3.42 \pm 0.03 \mathrm{mmHg}$. However, this effect was transient because a day after the experiment was over, IOP was restored to normal values.

\section{References}

1. Rastegar N, Eckart P, Mertz M. Radiation — induced cataract in astronauts and cosmonauts. Graefes Arch Clin Exp Ophthalmol. 2002; (240): 534-47.

2. Thomas H, Mader C, Robert OD, Anastas F. Optic Disc Edema, Globale Flattening, Choroidal Folds, and Hyperopic Shifts Observed in Astronauts after Long - duration Space Flight.
Such changes can be explained by a fluid shift in the body leading to an increased blood flow to the head and neck, including the choroid. The fluid shift causes the ocular volume to shrink and IOP to rise. As the body adapts to the conditions simulating a space flight, fluid and electrolytes are reabsorbed by renal tubules, the rate of glomerular filtration increases and urination becomes more frequent, speeding up clearance of osmotically active agents from the body. This brings IOP to its normal values [8]. Another possible explanation for our findings is that the fluid shift induces increased secretion of intraocular fluid but its drainage worsens [9].

\section{CONCLUSIONS}

1. Throughout the entire experiment that modelled hypogravity we observed a statistically significant and reliable increase in IOP $(p<0.01)$. 2. IOP increase under hypogravity conditions was transient, and IOP values went back to normal after the experiment was completed. 3. Direct ophthalmoscopy revealed no changes to the ocular fundus and the optic nerve head during the experiment. 4. Computerized perimetry also revealed no abnormalities induced by hypogravity. 
4. Cucinotta FA, Manuel FK, Jones J, et al. Space radiation and cataracts in astronauts. RADIAT Res. 2001; 460-6.

5. Frey MA. Radiation health: mechanism of radiation - induced cataracts in astronauts. Aviat Space Environ Med. 2009; 575-6.

6. Draeger J. Tonometry under microgravity condititions. Norderney Symposium on Scentific Results of the German Spacelab Mission D1. 1986; 503-9.

7. Mekjavic PJ, Eiken O, Mekjavic IB. Visual function after prolonged bed rest. J Gravit Physil. 2002; (9): 31-2.

\section{Литература}

1. Rastegar N, Eckart P, Mertz M. Radiation - induced cataract in astronauts and cosmonauts. Graefes Arch Clin Exp Ophthalmol. 2002; (240): 534-47.

2. Thomas H, Mader C, Robert OD, Anastas F. Optic Disc Edema, Globale Flattening, Choroidal Folds, and Hyperopic Shifts Observed in Astronauts after Long - duration Space Flight. American Academy of Ophthalmology Published by Elsevier Inc. 2011; 2058-70.

3. Chylack BE, Peterson LE, Feiveson AH, et al. NASA study of cataract is astronauts (NASA). Report 1: Cross - sectional study of the relationship of exposure to space radiation and risk of lens opacity. Radiat Res. 2009; (172): 10-20.

4. Cucinotta FA, Manuel FK, Jones J, et al. Space radiation and cataracts in astronauts. RADIAT Res. 2001; 460-6.
8. Kergoat H, Lovasik JV. Seven-degree head-down tilt reduces choroidal pulsatile ocular blood flow. Aviation, Space and Enviromental Medicine. 2005; 76 (10): 930-5.

9. Mader TH, Gibson GR, Pass AF, et al. Optic disc edema globe flattening, choroidal folds, and hyperopic shifts observed in astronauts after long-dyration space flight. Ophthalmology. 2011; (118): 2058-69.

5. Frey MA. Radiation health: mechanism of radiation - induced cataracts in astronauts. Aviat Space Environ Med. 2009; 575-6.

6. Draeger J. Tonometry under microgravity condititions. Norderney Symposium on Scentific Results of the German Spacelab Mission D1. 1986; 503-9.

7. Mekjavic PJ, Eiken O, Mekjavic IB. Visual function after prolonged bed rest. J Gravit Physil. 2002; (9): 31-2.

8. Kergoat H, Lovasik JV. Seven-degree head-down tilt reduces choroidal pulsatile ocular blood flow. Aviation, Space and Enviromental Medicine. 2005; 76 (10): 930-5.

9. Mader TH, Gibson GR, Pass AF, et al. Optic disc edema globe flattening, choroidal folds, and hyperopic shifts observed in astronauts after long-dyration space flight. Ophthalmology. 2011; (118): 2058-69. 